\title{
ANTIMICROBIAL SUSCEPTIBILITY OF CRUDE EXTRACTS OF Allium ascalonicum LINN. (WHOLE PLANT) AND Gladiolus psittacinus HOOK (CORM) AGAINST FIVE COMMON PATHOGENS: AN IN VITRO INVESTIGATION
}

\author{
IGBOKWE C.0.1, LAWAL T.0.1, OLORUNNIPA T.A. ${ }^{1}$, ADENIYI B.A. ${ }^{*}$ AND MAHADY G.B. ${ }^{2}$ \\ 1Department of Pharmaceutical Microbiology, Faculty of Pharmacy, University of Ibadan, Ibadan, Nigeria. \\ 2Department of Pharmacy Practice, College of Pharmacy, University of Illinois Chicago, Illinois 60612. \\ ${ }^{*}$ Corresponding Author: Email- baadeniyi@yahoo.co.uk
}

Received: August 08, 2012; Accepted: January 09, 2014

\begin{abstract}
Allium ascalonicum Linn. and Gladiolus psittacinus Hook., are two important plants cultivated across the world for their nutritional as well as medicinal values. In the quest for a more natural bioactive substance to check the rising incidence of antimicrobial resistance amongst pathogens, these two plants were in this study, screened for activity against five common pathogens; namely, Staphylococcus aureus ATCC 29213, Pseudomonas aeruginosa ATCC 27853, Escherichia coli ATCC 25922, Klebsiella pneumoniae ATCC 35657, and Candida albicans ATCC 90029. Phytochemical screening carried out on the extracts showed the presence of secondary metabolites like saponins, cardiac glycoside, alkaloids and flavonoids in both plant samples but only Allium ascalonicum yielded essential oil, while carbohydrate and tannins were detected in Gladiolus psittacinus. While the crude extracts of Gladiolus psittacinus did not show any inhibitory potential against any of the tested organisms, three pathogens were susceptible to Allium ascalonicum, with minimum inhibitory concentration (MIC) of 100 $\mathrm{mg} / \mathrm{mL}$. Bactericidal kinetics studies on the three pathogens showed that within the exposure time of 4 hours, the organisms were killed $(69 \%$ and $95 \%$ at $2 \times$ MIC and $4 \times$ MIC, respectively), a result which compared well with the positive control Gentamicin. The result of this study while agreeing with earlier reports on the non-activity of Gladiolus corms against Candida albicans contradicts the same report on the activity of the crude extract of this plant against Pseudomonas aeruginosa. The significant inhibitory potential of the crude methanolic extract of Allium ascalonicum against food borne pathogens such as Staphylococcus aureus, Escherichia coli and nosocomial pathogen such as Klebsiella pneumoniae, suggests that it can be explored as a natural alternative to chemical preservatives in food industries, and in the formulation of drugs against nosocomial infections .
\end{abstract}

Keywords- Allium ascalonicum Linn., Gladiolus psittacinus Hook., in vitro sensitivity, Bactericidal kinetics, phytochemical screening, secondary metabolites, nosocomial infection, pathogen

Citation: Igbokwe C.O., et al. (2014) Antimicrobial Susceptibility of Crude Extracts of Allium ascalonicum Linn. (Whole Plant) and Gladiolus psittacinus Hook (Corm) Against Five Common Pathogens: An In vitro Investigation. International Journal of Microbiology Research, ISSN: 0975-5276 \& E-ISSN: 0975-9174, Volume 6, Issue 1, pp.-510-514.

Copyright: Copyright@2014 Igbokwe C.O., et al. This is an open-access article distributed under the terms of the Creative Commons Attribution License, which permits unrestricted use, distribution and reproduction in any medium, provided the original author and source are credited.

\section{Introduction}

The menace of common pathogens like Staphylococcus aureus, Pseudomonas aeruginosa, Escherichia coli, Candida albicans, Klebsiella pneumonia etc., has remained a source of concern to healthcare providers. Staphylococcus aureus is a virulent pathogen that is currently the most common cause of infection in hospitalized patients [1]. The increase in the resistance of this pathogen to antimicrobial agents, coupled with its increasing prevalence as a nosocomial pathogen, is of major concern. It causes a wide range of suppurative infection, as well as food poisoning and toxic shock syndrome [2].

Pseudomonas aeruginosa is another very notorious pathogen. It is responsible for many nosocomial infections, and causes lifethreatening diseases in immunocompromized persons; and chronic infections in cystic fibrosis patients [3]. It is an opportunistic human pathogen and that of plants [4]. One most worrisome characteristics of $P$. aeruginosa, is its low antibiotic susceptibility, which is attribut- able to a concentrated action of multidrug efflux pumps with chromosomally-encoded antibiotic resistance genes [5]. Escherichia coli are commonly found in the lower intestine of warm-blooded organisms, most of which are harmless but some serotypes are pathogenic and cause serious food-poisoning in humans. They are responsible for occasional product-recalls $[3,6]$. Candida albicans, a diploid fungus that grows both as yeast and filamentous cells, are the causal agents of opportunistic oral and genital infections in human $[7,8]$. In recent years, Klebsiella have become important pathogen in nosocomial infections; and $K$. pneumoniae is clinically the most important member of the Klebsiella genus of Enterobacteriacea worrisomely, new antibiotic-resistant strains of $K$. pneumoniae are appearing, and it is increasingly found as a nosocomial infection [9].

Allium ascalonicum is an herb reported for its high medicinal values. Its properties are considered stomachic, tonic, anthelmintic, antispasmodic, aphrodisiac, diuretic, expectorant, febrifuge and hypo- 
tensive among others [10]. A member of the onion family, it is reported to have shown therapeutic potential against Helicobacter pylori, [11]. Its ethanolic and aqueous extracts have also been reported to inhibit the growth of Mycobacterium tuberculosis [12,13]. Partially purified extract of $A$. ascalonicum with sodium benzoate reportedly, synergistically inhibited all food-borne fungi, suggesting its use as food preservative, as to minimize the use of chemical preservatives $[14,15]$.

Gladiolus is an African medicinal plant recorded in the human pharmacopoeia. It is recorded (under several of its synonyms) as being used in southern Africa in the treatment of variety of ailments, including diarrhoea and colds [16]. In parts of West Africa, Gladiolus is used in preparations to cure both constipation and severe dysentery. In Ghana, Nigeria, Cameroon and Botswana; Gladiolus corms are used in food and in ethno-medicine for treating infections [17]. In Ghana and Igalaland (North-central Nigeria), G. psittacinus is actually cultivated on a small scale [18], while in south-western Nigeria, the corms called 'Baka' are used in treating gonorrhea, dysentery, and other infectious conditions.

\section{Materials and Methods}

\section{Collection of Plant Samples and Preparation of Extracts}

The plants samples- Allium ascalonicum Linn. and Gladiolus psittacinus Hook. were collected from Ogbomoso area of Oyo state Nigeria and authenticated at the herbarium in the Department of Botany, University of Ibadan, Ibadan, Nigeria. Voucher specimens were deposited for reference purposes, with the voucher numbers $\mathrm{UIH}-22337$ and $\mathrm{UIH}-22336$ for Allium ascalonicum Linn. and Gladiolus psittacinus Hook respectively. The $A$. ascalonicum plants were properly washed and air-dried while the corns of $G$. psittacinus were chopped into bits and sun-dried. They were later pulverized and packed into the Soxhlet extractor chamber. Continuous extraction process, using the $n$-hexane and methanol as solvents of choice, for 18 to 24 hours, was applied. The filtered extracts were concentrated using rotary evaporator; and dried. They were stored in a refrigerator until needed.

Various concentrations of the extracts viz: $200 \mathrm{mg} / \mathrm{mL}, 100 \mathrm{mg} / \mathrm{mL}$, $50 \mathrm{mg} / \mathrm{mL}, 25 \mathrm{mg} / \mathrm{mL}$ were prepared and used in this study.

\section{The Test-Microorganisms}

These include one Gram-positive organism, Staphylococcus aureus ATCC 29213; three Gram-negative organisms, Pseudomonas aeruginosa ATCC 27853, Escherichia coli ATCC 25922, Klebsiella pneumoniae ATCC 35657, and one fungal species, Candida albicans ATCC 90029. They were grown in the appropriate broth culture; Tryptic Soy broth (TSB) and subcultured overnight prior to the sensitivity testing to keep them in the log phase.

\section{Equipment and Other Items}

Autoclave (Gallenkamp), rotary evaporator, hot-air-oven, electronic weighing balance (mettler), Soxhlet extractor, water bath (Gallenk amp), various calibrated glassware, incubator (Gallenkamp), refrigerator, glass Petri dishes, pipettes, corkborer; media snutrient agar, Tryptic Soy broth, Mueller-Hinton agar, nutrient broth and Sabour aud dextrose agar.

\section{Phytochemical Screening}

The extracts were chemically analyzed for the presence of secondary metabolites such as anthraquinones, cardiac glycosides, flavo- noids, saponins, tannins, alkaloids as well as essential oil. This was done using the methods and techniques described by $[19,20]$.

\begin{abstract}
Antimicrobial Activity
Sterile plates were seeded with 1:100 dilution of fresh overnight culture of the test organisms [21], by introducing $0.2 \mathrm{~mL}$ of the organisms from the dilution into $20 \mathrm{ml}$ of molten Mueller-Hinton agar (for bacteria) and Sabouraud dextrose agar (for fungal species) kept at $45^{\circ} \mathrm{C}$. The mixture was properly blended in a universal bottle before pouring into the plates and allowed to set. A sterile cork borer of $8 \mathrm{~mm}$ diameter was used to make uniform and equidistant wells on the seeded plates. One hundred microlitre $(100 \mu \mathrm{L})$ of the resuspended extracts was placed in the wells using sterile pipettes, the positive and negative controls were also placed in their respective wells. The plates were allowed to stand on the bench for an hour to ensure proper diffusion before incubation. After 24-hour incubation at $37^{\circ} \mathrm{C}$ for bacteria species, and 2 to 3 days at $25^{\circ} \mathrm{C}$ for fungal species, the plates were observed for zones of inhibition, which were measured to the nearest millimeter $(\mathrm{mm})$ with a standard transparent meter rule. All tests were performed in duplicates.
\end{abstract}

\section{Determination of Minimum Inhibitory Concentration (MIC)}

The agar dilution technique [22] was adopted to determine the MIC for susceptible organisms. The resuspended extracts were prepared to final concentrations of $200 \mathrm{mg} / \mathrm{mL}, 100 \mathrm{mg} / \mathrm{mL}, 50 \mathrm{mg} / \mathrm{mL}$, $25 \mathrm{mg} / \mathrm{mL}$ and $12.5 \mathrm{mg} / \mathrm{mL}$. $1 \mathrm{~mL}$ of each concentration was introduced into $19 \mathrm{~mL}$ of molten Mueller-Hinton agar maintained at $45^{\circ}$ C. The properly blended mixture was poured into sterile Petri dishes and allowed to set before removal of moisture in a sterile dryer. The test organisms from a fresh overnight broth culture were streaked on the surface of the dried agar in plates. The plates were incubated at $37^{\circ} \mathrm{C}$ for 24 hours after which they were examined for growth, recording the lowest concentration that prevented the growth of the organisms as their minimum inhibitory concentration. All the tests were performed in duplicates.

\section{Extracts' Kill-Kinetics}

Concentrations of extracts corresponding to that of MIC, 2xMIC, 4xMIC, 8xMIC were used, by a modification of methods described by [21]. One hundred microlitre $(100 \mu \mathrm{L})$ of fresh overnight culture of the susceptible organisms, maintained in a sustained log phase of growth, was added into $3.9 \mathrm{~mL}$ of Tryptic soy broth, containing 1 $\mathrm{mL}$ of the extract, to give a 5 -fold dilution. This formed the stock for each concentration. $0.1 \mathrm{~mL}$ of the stock was aseptically withdrawn to carry out serial dilution, and $0.1 \mathrm{~mL}$ of the final dilution, plated out on a solidified, sterile Mueller-Hinton agar. A sterile glass rod was used to spread the inoculums. The withdrawal from the stock was strictly done at time intervals of 0 hour, 0.5 hour 1.0 hours, 2.0 hours, 4.0 hours, 6 hours, and 24 hours, for the various concentrations; and this also ran simultaneously with the drug-positive control and organism-negative control. The plates were incubated at $37^{\circ} \mathrm{C}$ for 24 to 48 hours, after which the number of colonies on each plate was counted, and the colony forming unit (CFU), calculated taking into account the final volume inoculated and the dilution factor. The rate of kill was determined from the percentage survival of the organisms. This was presented on a semi-logarithm graph. All tests were performed in duplicates.

\section{Results}

The percentage yield and macroscopic features of the plants ex- 
tracts are presented in [Table-1] while the results of the phytochemical screening of samples are as shown in [Table-2]. [Table-3] and [Table-4] show the results of the antimicrobial sensitivity testing as well as the minimum inhibitory concentration of the active extract on the test organisms. The bactericidal activities of bioactive methanol extract on test pathogens are depicted in [Fig-1], [Fig-2] and [Fig-3] showing the percentage kill of the organism at different exposure time.

Table 1- Percentage yield and macroscopic analysis of $n$-Hexane and Methanol extracts of Allium ascalonicum Linn. and Gladiolus psittacinus

\begin{tabular}{|c|c|c|c|c|c|}
\hline \multirow{2}{*}{ Plant species } & \multirow{2}{*}{ Weight of Samples (g) } & \multicolumn{2}{|c|}{$\%$ yield } & \multicolumn{2}{|c|}{ Macroscopic Analysis } \\
\hline & & Hexane fraction & Methanol fraction & Hexane fraction & Methanol fraction \\
\hline $\begin{array}{l}\text { Allium ascalonicum (whole plant) } \\
\text { Gladiolus psittacinus (Dried corm) }\end{array}$ & $\begin{array}{c}543 \\
810.8\end{array}$ & $\begin{array}{l}1.98 \\
1.86\end{array}$ & $\begin{array}{c}17.7 \\
19.59\end{array}$ & $\begin{array}{l}\text { Greenish-yellow (solid) } \\
\text { Pale-yellow (viscous liquid) }\end{array}$ & $\begin{array}{l}\text { Dark-brown (paste) } \\
\text { Brown (paste) }\end{array}$ \\
\hline
\end{tabular}

Table 2- Phytochemical screening of the extracts of Allium ascalonicum Linn. and Gladiolus psittacinus Hook.

\begin{tabular}{lcc|}
\hline Phytochemicals & A. ascalonicum & G. psittacinus \\
\hline Alkaloids & ++ & ++ \\
Anthraquinones & - & - \\
Cardiac glycosides & ++ & ++ \\
Carbohydrates & - & ++ \\
Flavonoids & ++ & ++ \\
Saponins & + & ++ \\
Tannins & - & ++ \\
Essential oil & ++ & - \\
Terpernoids & - & - \\
Note: $+=$ present in moderate concentration & \\
\hline
\end{tabular}

Table 3- Antimicrobial Sensitivity of the five common Pathogens to the extracts of Allium ascalonicum Linn. and Gladiolus psittacinus Hook. at $100 \mathrm{mg} / \mathrm{mL}$. Zone of inhibition $(\mathrm{mm}) \pm$ SEM

\begin{tabular}{|c|c|c|c|c|c|}
\hline Organism & $\begin{array}{l}\text { A. asc } \\
\text { n-Hexan }\end{array}$ & $\begin{array}{l}\text { alonicum } \\
\text { e Methanol }\end{array}$ & $\begin{array}{r}\text { G. psit } \\
\text { n-Hexane }\end{array}$ & $\begin{array}{l}\text { tacinus } \\
\text { Methanol }\end{array}$ & $\begin{array}{l}\text { Gentamicin } \\
\text { (80 } \mu \mathrm{g} / \mathrm{ml})\end{array}$ \\
\hline S. aureus ATCC 29213 & NA & $16 \pm 0.20$ & NA & NA & $20 \pm 0.40$ \\
\hline P. aeruginosa ATCC27853 & NA & NA & NA & NA & NA \\
\hline E. coli ATCC25922 & NA & $16 \pm 0.25$ & NA & NA & $21 \pm 0.50$ \\
\hline K. pneumonia ATCC35657 & NA & $17 \pm 0.05$ & NA & NA & $21 \pm 0.20$ \\
\hline C. albicans ATCC90029 & NA & NA & NA & NA & NA \\
\hline \multicolumn{6}{|c|}{$\begin{array}{l}\text { Note: Diameter of cork borer }=8 \mathrm{~mm} ; \mathrm{NA}=\text { No Activity; Results are average of dupli- } \\
\text { cate experiments }\end{array}$} \\
\hline
\end{tabular}

Table 4- Minimum Inhibitory Concentration (MIC) of methanol extract of Allium ascalonicum Linn. on the test pathogens

\begin{tabular}{|c|c|c|c|c|c|}
\hline Extracts (mg/mL) & S. aureus ATCC 29213 & P. aeruginosa ATCC 27853 & E. coli ATCC 25922 & K. pneumonia ATCC 35657 & C. albicans ATCC 90029 \\
\hline A. ascalonicum (mg/mL) & 100 & ND & 100 & 100 & ND \\
\hline Gentamicin $(\mu \mathrm{g} / \mathrm{mL})$ & 80 & ND & 80 & 80 & ND \\
\hline
\end{tabular}

\section{Discussion and Conclusion}

In the quest for plants with the right composition and combination of phytochemical compounds as possible antidote to the problems of drug-resistance amongst pathogenic microorganisms, this study investigated susceptibility of five common pathogens to the crude $n$ hexane and methanol extracts of Allium ascalonicum (whole plant) and Gladiolus psittacinus (dried corm). The yield of the methanol fraction of the extract was more than the yield of $n$-hexane fraction of the extract [Table-1]. The non-polar nature of $n$-hexane must have contributed to its low percentage yield as shown in [Table-1] because during extraction process, solvents diffuse into the solid plant material and solubilise compounds of similar polarity. This is known to affect the quantity and composition of secondary metabolites of the extract [23]. The qualitative phytochemical analysis of the plant extracts revealed the presence of secondary metabolites such as alkaloids, flavonoids, saponins, and cardiac glycosides, in both plant samples but only $G$. psittacinus yielded tannins and carbohydrate, while essential oil was found in A. ascalonicum. Anthraquinones and terpernoids were not detected [Table-2].

The lack of inhibitory potential observed in the methanol extract of G. psittacinus against the common pathogens may not necessarily mean the absence of bioactive constituents; but may be due to its poor diffusion rate as observed in this study [Table-3], occasioned by the high molecular weight of the extract. In contrast, the methanol extract of $A$. ascalonicum showed significant inhibitory potential against three of the investigated pathogens. $S$. aureus ATCC 29213, E. coli ATCC 25922, K. pneumoniae ATCC 35657 [Table-3] due to the presence and right combination of the secondary metabolites, as well as the high diffusion rate and also, the presence of essential oil which being lipophilic in nature, makes permeability to cellular membrane easy [24]. The antimicrobial properties exhibited by the methanol extract of $A$. ascalonicum could be traced to the presence of alkaloids, flavonoids, saponins, and cardiac glycosides and most especially essential oil. These phytochemical compounds are biologically active and thus aid the antimicrobial activities of $A$. ascalonicum. Phytochemicals exert antimicrobial activity through different mechanisms.

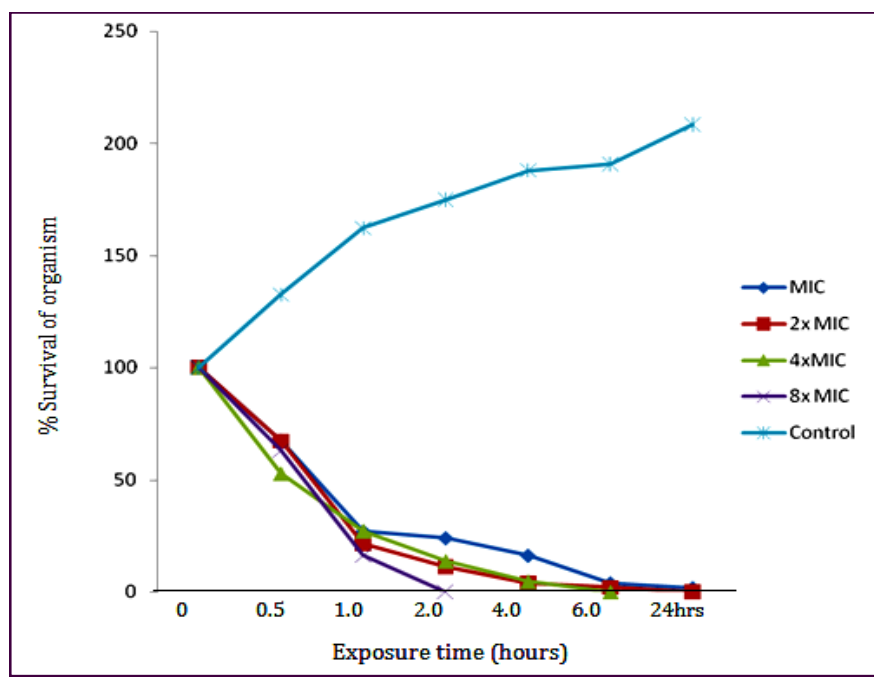

Fig. 1- Kinetics of bactericidal activities of methanol extract of $A$. ascalonicum on S. aureus ATCC 29113, showing the rate of kill of the organism by the extract at different exposure time.

The resistance or low antibiotics susceptibility of $P$. aeruginosa has been attributed to a concerted action of multidrug efflux pumps with chromosomally-encoded antibiotic resistant genes [5]; and unusual- 
ly large number of genes for catabolism, nutrient transport, efflux of organic molecules and metabolic regulations [25]. Also C. albicans which showed resistance to the plant extracts in this study as shown in [Table-3] have been reported to have several mechanisms of antimicrobial resistance [26-28].

In agreement with its MIC value of $100 \mathrm{mg} / \mathrm{mL}$ as shown in [Table4], the bactericidal kinetics showed that at concentrations equivalent to $2 \times$ MIC and $4 \times$ MIC, the susceptible organisms were killed (69\% kill and 95\% kill respectively), within 4 hours exposure time [Fig-1] to [Fig-3]. The killing was both dose and time dependent as shown in the graph. This compared well with the drug-positive control which killed the organisms at about the same contact time though at a much lower concentration [Fig-1] to [Fig-3]. The bactericidal activity exhibited by the drug control is expected since it is a pure drug unlike the methanol extract which may have a lot components acting together at the same time; the action/activity which may be synergistic, additional or even antagonistic.

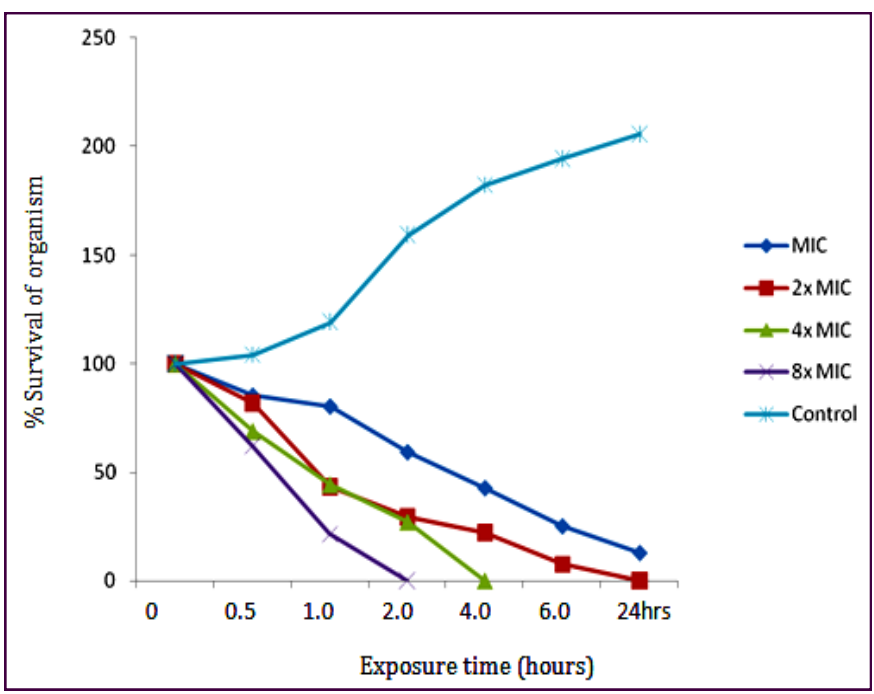

Fig. 2- Kinetics of bactericidal activities of methanol extract of Allium ascalonicum on Escherichia coli ATCC 25922, showing rate of kill of the organism by the extract at different exposure time.

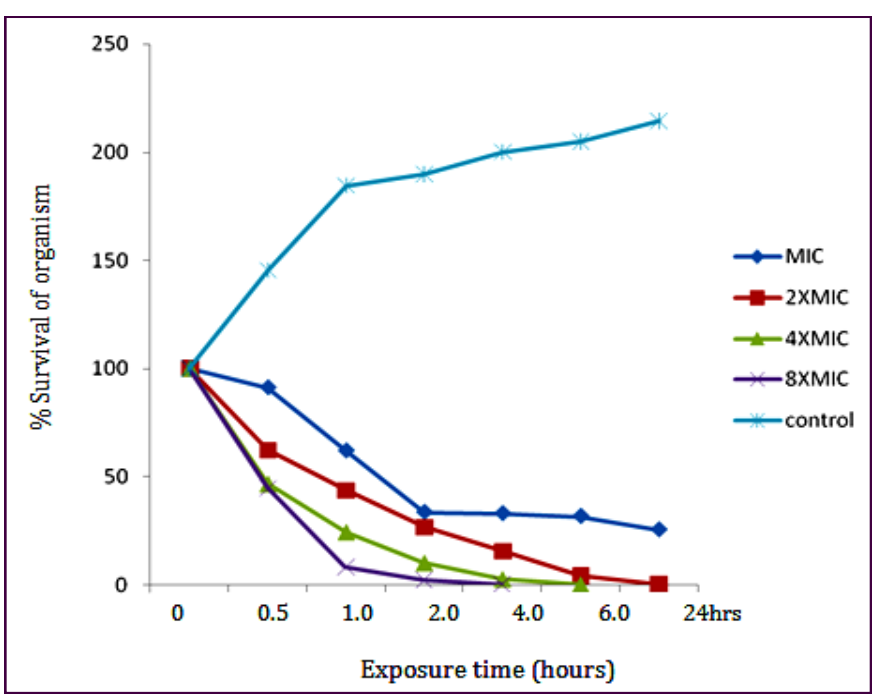

Fig. 3- Kinetics of bactericidal activities of methanol extract of Allium ascalonicum on Klebsiella pneumoniae ATCC 35657, showing rate of kill of the organism by the extract at different exposure time.

\section{Conclusion}

In conclusion, while the crude extract of G. psittacinus did not show inhibitory potential against any of the common pathogens investigated, further purification of the bioactive constituents may yield a better result. The significant inhibitory potential displayed by the methanol extract of $A$. ascalonicum against common food-borne pathogens like $S$. aureus, $E$. coli, and nosocomial pathogen like $K$. pneumoniae suggests that it can be used as a possible natural preservative in food industries as to reduce the risks involved in the use of chemical preservatives and also in formulation of drugs against infections involving nosocomial pathogens.

Conflicts of Interest: None declared.

\section{References}

[1] Emori T.G. and Gaynes R.P. (1993) Clin. Microbiol. Rev., 6, 428-442.

[2] Todar K. (2007) Pathogenic E. coli, Textbook of Bacteriology, University of Wisconsin-Madison, Department of Bacteriology Retrieved.

[3] CDC Division of Bacterial and Mycotic Diseases (2010) Escherichia coli 0157:H7.

[4] Brooks G.F., Carroll K.C., Butel J.S., Morse S.A. (2007) Medical Microbiology, 24th ed., MacGraw Hill, New York, 263-266.

[5] Poole K. (2004) Clinical Microbiology and Infection, 10(1), 1226.

[6] Dippold L. and Vogt R.L. (2005) Public Health Rep., 120(2), 174 $-178$.

[7] Ryan K.J. and Ray C.G. (2004) Sherries Medical Microbiology, 4th ed., McGraw Hill, 120.

[8] Enfert C. and Hube B. (2007) Candida: Comparative and Functional Genomics. Caister Academic Press, 7-7.

[9] Coovadia T.M., Johnson A.P., Bhna R.H., Hutchinson G.R., George R.C. and Hafferjee I.E. (1992) J. Hosp. Infect., 22, 197205.

[10]Mohammadi-Motlagh H.R., Mostafaie A. and Mansouri K. (2011) Arch. Med. Sci., 7(1), 38-44.

[11]Adeniyi B.A. and Anyiam F.M. (2004) Phytotherapy Research, 18(5), 358-361.

[12]Adeleye I.A., Onibogu C.C., Ayolabi C.I., Isawumi A.O. and Nshiogu M.E. (2008) African Journal of Biotechnology, 7(18), 3182-3187.

[13]Mansour A., Sepideh S. and Mohammad H. (2009) Jundishapur Journal of Microbiology, 2(4), 144-147.

[14]Amin M., Raut A.D., Sathe S.J. and Kapadmis B.P. (2006) Journal of Food Science and Technology, 43(4), 344-348.

[15]Zaika L.L. (1998) J. Food Safety, 9, 97-118.

[16]Ameh S.J., Obodozie O.O., Olorunfemi P.O., Okoliko I.E. and Ochekpe N.A. (2011) Journal of Microbiology and Antimicrobials, 3(1), 8-12.

[17]Assob Nguedia J.C., Etoa F.X., Penlap Beng V., Lontsi D., Kuete V. and Somo Moyou R. (2004) Pharm. Méd. Trad. Afr., 13, 149-159.

[18]Hutchinson J. and Dalziel J.M. (1968) Gladiolus Linn (2: 376), The useful Plants of Tropical West Africa, The Crown Agent for the Colonies, 4 Millbank, Westminstr, London, SW1, 487-488. 
[19]Abo K.A. and Adeyemi A.A. (1999) Introductory Practical Phytochemistry, Pharmacognosy Practical, Schedule II, Department of Pharmacognosy, Faculty of Pharmacy, Olabisi Onabanjo University, Sagamu.

[20]Trease G.E. and Evans W.C. (1989) Pharmacognosy, 11th ed., Brailliar, Turidel Can., Macmillian Publishers, 60.

[21]Aibinu I., Adenipekun T., Adelowotan T., Ogunsanya T. and Odugbemi T. (2007) African Journal of Traditional, Complementary, and Alternative Medicines, 4(2), 185-195.

[22]Russell A.D. and Furr F.R. (1977) J. Applied Bact., 43, 253-260.

[23]Parekh J., Karathia N. and Chanda S. (2006) Indian J. Pharm. Sci., 68(6), 832-834.

[24]Bakkali F., Averbeck S., Averbeck D. and Idaomar M. (2008) Food Chem. Toxicol., 46, 446-475.

[25]Prescott L.M., Harley J.P. and Klein D.A. (2002) Microbiology, 5th ed., McGraw Hill, 504.

[26]Vander Bossche H., Marichal P., Gorrens J., Bellens D., Moereels $\mathrm{H}$ and Janseen P.A. (1990) Biochemical Society Transactions, 18, 56-59.

[27]Warlu K., Denning D.W., Manning N.J. and Kelly S.L. (1996) Antimicrobial Agents and Chemotherapy, 40, 1382-1386.

[28]Lamb D.C., Kelly D.E., Schunck W.H., Shyadehi A.Z., Akhtar M., Lowe D.J., Baldwin B.C. and Kelly S.L. (1997) Journal of Biological Chemistry, 272, 5682-5688. 